\title{
ANALISIS KOMPETENSI PERAJIN SULAMAN MINANG
}

\author{
LENNY HASAN DAN HAFRIZAL OKTA ADE PUTRA \\ Fakultas Ekonomi Universitas Tamansiswa, Padang
}

Tujuan penelitian ini adalah untuk mengetahui pengaruh kompetensiyang dimiliki perajin sulaman minang terhadap hasil sulaman minang di kelurahan koto panjang ikur koto kota Padang. Populasi dalam penelitian ini adalah pengrajin sulaman dikelompok Anisa dan kelompok Mawar.Jumlah sampel dalam penelitian ini adalah 60 responden, dengan menggunakan teknik penarikan sampel sampling jenuh, untuk membuktikan kompetensi dapat mempengaruhipengetahuan dan keterampilan dari pengrajin sulaman dikelompok Anisa dan Mawar ikur koto kota Padang maka Penulis menggunakan teknik analisis kuantitatif dengan menggunakan pengujian hipotesis secara statistik. Tahapan pengujian yang penulis lakukan meliputi uji regresi linear berganda dan uji hipotesis, seperti uji t-statistik, dan uji koefisien determinasi. Berdasarkan hasil penelitian diketahui pengetahuan berpengaruh signifikant terhadap variabel kompetensi secara parsial dimana nilai thitung variabel pengetahuan adalah 0.289 dengan probabilitas signifikan sebesar 0.774. Probabilitas signifikansi tersebut lebih kecil dari 0,05. Dengan $\mathrm{df}=\mathrm{n}-\mathrm{k}=60-2=58$ diperoleh ttabel sebesar 1.672, dari hasil di atas dapat dilihat bahwa thitung $>$ ttabel atau $0.289>1.672$, maka variabel pengetahuan berpengaruh signifikan terhadap kompetensi. Hasil uji t, diketahui keterampilan berpengaruh signifikant terhadap variabel kompetensi secara parsial dimana nilai thitung variabel keterampilan adalah 5.048 dengan probabilitas signifikan sebesar 0,000. Probabilitas signifikansi tersebut lebih kecil dari 0,05. Dengan $\mathrm{df}=\mathrm{n}-\mathrm{k}=60-2=58$ diperoleh ttabel sebesar 1.672, dari hasil di atas dapat dilihat bahwa thitung $>$ ttabel atau $0.000<1.672$, maka variabel keterampilan berpengaruh signifikan terhadap kompetensi.Hasil uji R2diperoleh 0,373 hal ini berarti besarnya pengaruh pengetahuan danketerampilan secara bersama-sama perpengaruh terhadap kompetensi penyulam di Kelurahan Koto Panjang Ikur Koto Kota Padang adalah sebesar $37,3 \%$ sisanya sebesar $62.7 \%$ dijelaskan oleh variabel lain yaitu yang tidak masuk ke dalam penelitian ini.

Keywords: Pengetahuan, Keterampilan, Kompetensi 


\section{LATAR BELAKANG}

Salah satu yang cukup diunggulkan dari Tanah Minang ini adalah kerajinan sulaman, bordir serta krancangnya. Warna dan corak yang beragam serta pembuatan yang dikerjakan dengan tangan menjadi keunggulan tersendiri dari kerajinan sulaman serta bordir dari Sumatera Barat.Ciri khas bordir Minang dengan Jawa Barat misalnya, sangat berbeda, mulai dari cara pengerjaan, motifnya, hasil bordirnya sampai cara mengerjakannya di Minang perajin sulaman masih mengerjakannya dengan tangan sehingga menghasilkan karya yang lebih halus dan rapi. Ciri khas lainnya, bordir dan sulam Minang lebih banyak menampilkan motifmotif bunga yang digabungkan dengan gambar hewan maupun dedaunan, serta ciri khas kerajinan sulam Minang juga mudah dikenali lewat warnanya lebih dominan warna merah, orange muda, hijau, cokelat dan pink yang juga mengarah ke warna alam.

Menyulam adalah salah satu teknik menghias kain, dengan tujuan meningkatkan kualitas tampilan kain. Sejak awal keberadaanya seni ini sudah banyak menarik perhatian, terutama kaum perempuan dari semua usia dan golongan. Mereka berkelompok mengisi waktu luang dengan membuat sulaman. Berbagai produk sulam dibuat dengan aneka teknik dan motif hias, mulai dari produk rumah tangga sampai busana pesta. Sulaman banyak dibuat oleh kaum perempuan, walaupun sulaman para perempuan tersebut sangat indah, namun mereka tidak mempelajarinya secara khusus. Mereka saling bertukar pengalaman, dengan kata lain mereka belajar secara otodidak. Dampaknya adalah karakteristik "keheterogenan" cukup kental disini. Heterogenusia dan latarbelakang, pendidikannya, dan heterogen standar kompetensinya.
Jika awalnya keterampilan sulam merupakan pekerjaan sambilan dirumah, kini keterampilan ini menjadi suatu keterampilan yang memiliki daya jual, yang dibutuhkan di dunia industri.Dunia industri membutuhkan tenaga kerja yang jelas kualifikasi danstandar kompetensinya, karena kemajuan teknologi telah menghasilkan bahanbahan, alat dan mesin-mesin yang berguna meningkatkan kualitas sulaman, maka perlu dibuat suatu standar kompetensi yang harus dimiliki oleh seorang perajin sulaman,sebagai acuan dalam menetapkan standar hasil sulaman agar produk sulaman Indonesia terutama daerah Sumatera Barat dapat bersaing dengan sulaman-sulaman dari propinsi-propinsi lain. Standar kompetensi sulaman ini akan menjadi arah dan landasan untuk mengembangkan sulaman yang lebih baik lagi dari segi kualitasnya.

Penelitian ini akan menganalisis kompetensi yang dimiliki oleh perajin sulaman minang didaerah kota Padang tepatnya dikelurahan koto panjang ikur koto kec. Koto tangah. Dimana masyarakat di koto panjang ikua koto ini aktif dalam kegiatan pelatihan sulaman yang diadakan oleh Dinas Perindustrian Perdagangan Pertambangan dan Energi kota Padang. Telah ada kelompok-kelompok perajin sulaman di kelurahan koto panjang ikur koto yang tetap aktif berproduksi dan berkarya dalam sulaman.Melihat fenomena ini, peneliti tertarik untuk meneliti lebih lanjut, kompetensi seperti apa yang harus dimiliki perajin sulaman minang untuk menghasil sulaman yang bagus dan berdaya jual tinggi.

Para perajin sulaman harus mempunyai kompetensi yang bagus dalam kemampuan, pengetahuan dan keahlian sehingga tujuan yang ingin dicapainya yaitu untuk menghasilkan sulamansulaman yang bagus dapat tercapai sehingga nantinya dapat menghasilkan sulaman-sulaman

Tabel 1

Daftar perajin Sulaman dikelurahan Ikur Koto di Kota Padang Tahun 2016

\begin{tabular}{cccc}
\hline No. & Kelompok Pengrajin & $\begin{array}{c}\text { Jumlah } \\
\text { Anggota }\end{array}$ & Alamat \\
\hline 1. & KelompokAnnisa & 30 & $\begin{array}{l}\text { J. Perum PUSKUD Minang Blok D8 Rt 02/Rw 05 } \\
\text { Kec. Panjang Ikur Koto Koto Tangah }\end{array}$ \\
\hline 2. & KelompokMawar & 30 & $\begin{array}{l}\text { Jl. Perum PUSKUD Minang Blok D8 Rt 02/Rw 06 } \\
\text { Kec. Panjang Ikur Koto Koto Tangah }\end{array}$ \\
\hline Jumlah & 60 & \\
\hline
\end{tabular}

Sumber: Dinas Perindustrian Perdagangan Pertambangan dan Energi Kota Padang, 2016. 
yang berkualitas baik dan berdaya jual beli tinggi.

Berdasarkan beberapa fenomena di atas, terlihat bahwa masih kurang banyaknya produk sulaman minang karena kekurangan tenaga perajin dalam menghasilkan produk sulaman minang serta masih kurang baiknya kualitas produk sulaman minang yang dihasilkan oleh perajin. Untuk itu penulis tertarik untuk meneliti lebih lanjut kompetensi apakah yang harus dimiliki oleh perajin sulaman minang.

\section{TINJAUAN TEORITIS}

\section{Kompetensi}

Pengertian kompetensi menurut Sutrisno (2012:204) adalah tugas, keterampilan, sikap dan apresiasi yang harus dimiliki sumber daya manusia untuk dapat melaksanakan tugas-tugas pekerjaan sesuai dengan yang dibebankan kepada sumber daya manusia tersebut. Kompetensi menurut Spencer \& Spencer dalam Palan (2007) adalah sebagai karakteristik dasar yang dimiliki oleh seorang individu yang berhubungan secara kausal dalam memenuhi kriteria yang diperlukan dalam menduduki suatu jabatan. Pengertian kompetensi menurut Peraturan Presiden No. 8 tahun 2012 adalah akumulasi kemampuan seseorang dalam melaksanakan suatu pekerjaan secara mandiri, bertanggung jawab dan terukur melalui suatu asesmen yang baik.

Spencer dan Spencer dalam Uno(2007:63), kompetensi merupakan karakteristik yang menonjol bagi seseorang dan menjadi cara-cara berperilaku dan berfikir dalam segala situasi,dan ber- langsung dalam periode waktu yang lama. Dari pendapat tersebut dapat dipahami bahwa kompetensi menunjuk pada kinerja seseorang dalam suatu pekerjaan yang bisa dilihat dari pikiran, sikap, dan perilaku. Selanjutnya Dessler (2004: 713) menyatakan bahwa kompetensi adalah mengacu pada pengetahuan (knowledge), keterampilan (skill), individu yang secara langsung mempengaruhi kinerja.

\section{Karakteristik Kompetensi}

Menurut Spencer dan Spencer dalam Wibowo (2007) menyatakan bahwa ada lima karakteristik kompetensi yaitu sebagai berikut:

1. Motif (motive), adalah sesuatu apa yang secara konsisten dipikirkan atau keinginan-keinginan yang menyebabkan melalukan tindakan. Apa yang mendorong, perilaku yang mengarah dan dipilih terhadap kegiatan atau yujuan tertentu.

2. Sifat atau ciri bawaan (Trait), ciri fisik dan reaksi-reaksi yang bersifat konsisten terhadap situasi atau informasi.

3. Konsep diri (Selft Concept), sikap, nilai atau citra diri seseorang (self image). Percaya diri merupakan keyakinan orang bahwa mereka dapat efektif dalam hampir setiap situasi adalah bagian dari konsep diri orang.

4. Pengetahuan (knowledge), yaitu suatu informasi yang dimiliki seseorang khususnya pada bidang spesifik.

5. Keterampilan (Skill), kemampuan untuk mampu melaksanakan tugas-tugas fisik dan mental tertentu.

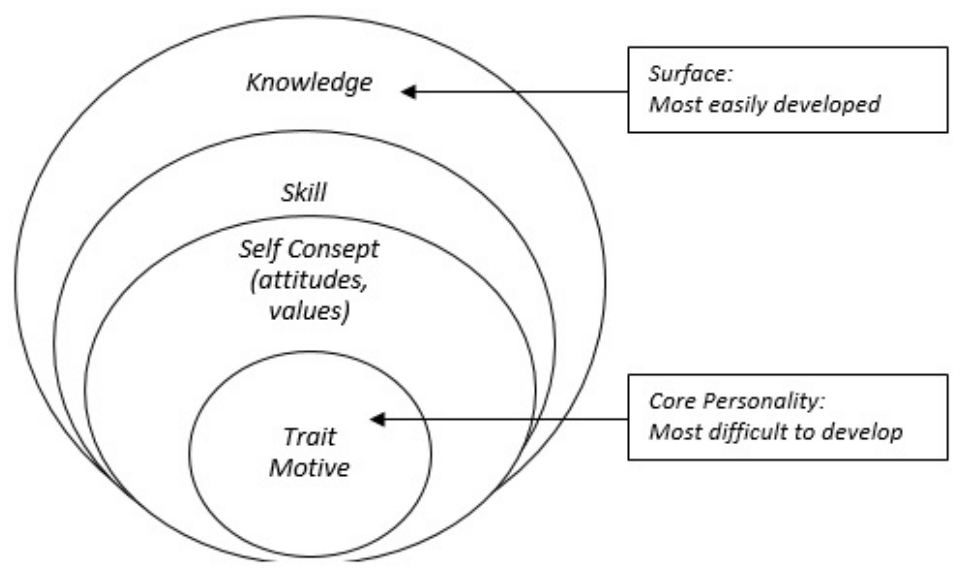

Gambar 1. Lima Karakteristik Kompetensi

Sumber: Spencer dan Spencer dalam Wibowo, 2007 
Inti kompetensi motif (motive) dan sifat (trait) berada pada dasar sehingga sulit untuk dinilai dan dikembangkan serta memakan biaya yang besar. Sedangkan konsep diri (self concept) berada diantara keduanya. Sikap (attitudes) dan nilai (values) seperti percaya diri (self confidence) dapat diubah melalui pelatihan dan psikoterapi atau pengalaman pengembangan yang positif, walaupun memerlukan jangka waktu yang lebih lama dan sulit.

\section{Manfaat Kompetensi}

Dessler (2004:715) mengemukakan manfaat kompetensi sebagai berikut:

1. Untuk mengetahui cara berfikir sebab akibat yang kritis.

Hubungan strategis antara sumber daya manusia dan kinerja adalah peta strategis yang menjelaskan proses implementasi strategis tersebut. Peta strategis ini merupakan kumpulan hipotesis mengenai hal apa yang menciptakan nilai (value) dalam perusahaan.

2. Memahami prinsip pengukuran yang baik.

Pondasi dasar kompetensi manajemen manapun sangat tergantung pada pengukuran yang baik, khususnya pengukuran harus menjelaskan dengan benar kontruksi tersebut.

3. Memastikan hubungan sebab akibat (causal).

Berpikir secara klausal dan memahami prinsip pengukuran membantu dalam memperkirakan hubungan klausal antara sumber daya manusia dan kinerjanya.

4. Mengkomunikasikan hasil kerja strategis sumber daya manusia pada atasan.

Untuk mengukur kinerja strategis sumber daya manusia, harus mampu mengkomunikasikan pemahaman mengenai dampak strategies sumber daya manusia pada atasan, khususnya perlu memahami bahwa mereka akan memberikan pertanyaan yang bagaimana hasil sistem pengukuran sumber daya manusia akan menilai jawaban bagi pertanyaan mereka.

\section{Indikator Kompetensi}

Indikator kompetensi menurut Dessler (2004) yaitu:

a. Pengetahuan (knowledge), adalah informasi yang dimiliki seseorang dibidangtertentu.

b. Keterampilan (skill), adalah adalah kemamp- uan untuk melaksanakan suatu tugas tertentu baik secara fisik maupun mental.

Kompetensi pengetahuan (Knowledge Competencies) dan keterampilan (Skill Competencies) cenderung lebih nyata (visible) dan relatif berbeda yang dimiliki manusia.

Indikator kompetensi menurut peraturan Presiden No. 8 tahun 2012 tentang standar kompetensi lulusan (SKL) kursus dan pelatihan sulam, yaitu:

a. Memilih desaian dan tekstil sesuai teknik bordir/sulam.

b. Terampil mengerjakan berbagai teknik bordir/ sulam.

c. Mengkombinasikan beberapa model bordir/ sulam pada suatu produk.

\section{Jenis Kompetensi}

Menurut Byham dalam Yuniarsih dan Suwatno (2011:28) pada dasarnya kompetensi terdiri dari tiga kategori atau jenis, yaitu:

1. Kompetensi organisasi (organizational competencies), faktor unik yang membuat organisasi kompetitif.

2. Kompetensi pekerjaan atau peran (job/role competencies), sesuatu yang harus ditunjukkan oleh individu agar menjadi efektif dalam pekerjaan, peran, fungsi, tugas atau kewajiban pada tingkat organisasi atau pada seluruh organisasi.

3. Kompetensi personal (personal competencies), aspek dari individu yang menunjukkan tingkat keterampilan, prestasi atau output.

\section{Pengetahuan}

Mempunyai kompetensi yang baik maka seorang individu harus memiliki pengetahuan yang luas dan terkini agar dapat menyesuaikan dengan perubahan yang terjadi. Menurut Notoatmojo, (2007) pengetahuan adalah hasil "tahu" dan ini terjadi setelah orang melakukan pengindraan terhadap suatu objek tertentu. Pengindraan terjadi melalui panca indra manusia, yakni indra penglihatan, pendengaran, penciuman, rasa dan raba.

Sebagian besar pengetahuan manusia di peroleh melalui mata dan telinga. Pengetahuan adalah merupakan hasil mengingat suatu hal, termasuk mengingat kembali kejadian yang pernah dialami baik secara sengaja maupun tidak sengaja 
dan ini terjadi setelah orang melakukan kontak atau pengamatan terhadap suatu obyek tertentu (Mubarak, 2007). Menurut Peraturan Presiden No. 8 tahun 2012 pengertian pengetahuan adalah penguasaan dan pemahaman tentang konsep, fakta, informasi, teori dan metodologi pada bidang keilmuan, keahlian dan pekerjaan tertentu oleh seseorang.

\section{Faktor yang mempengaruhi pengetahuan}

Menurut Mubarak (2007) beberapa faktor yang dapat mempengaruhi pengetahuan seseorang, yaitu :

1. Umur, usia adalah umur yang terhitung mulai saat dilahirkan sampai saat ia akan berulang tahun. Semakin cukup umur, tingkat kematangan dan kekuatan seseorang akan lebih matang dalam berpikir dan bekerja. Hal ini sebagai akibat dari pengalaman dan kematangan jiwanya.

2. Pendidikan, makin tinggi tingkat pendidikan seseorang maka makin mudah dalam menerima informasi, sehingga semakin banyak pula pengetahuan yang dimiliki.

3. Lingkungan, adalah seluruh kondisi lingkungan yang ada di sekitar manusia sebagai input kedalam diri seseorang sehingga sistem adaptif yang melibatkan baik faktor internal maupun faktor eksternal. Seseorang yang hidup dalam lingkungan yang berpikiran luas maka pengetahuannya akan lebih baik daripada orang yang hidup di lingkungan yang berpikiran sempit.

4. Pekerjaan, adalah serangkaian tugas atau kegiatan yang harus dilaksanakan atau diselesaikan oleh seseorang sesuai dengan jabatan atau profesi masing-masing. Status pekerjaan yang rendah sering mempengaruhi tingkat pengetahuan seseorang.

5. Informasi yang diperoleh, Pemberian informasi seperti cara-cara pencapaian hidup sehat akan meningkatkan pengetahuan masyarakat yang dapat menambah kesadaran untuk berperilaku sesuai dengan pengetahuan yang dimiliki.

\section{Keterampilan}

Keterampilan kerja memiliki manfaat yang besar bagi individu, untuk dapat meningkatkan hasil kerjanya sehingga memperoleh balas jasa yang sesuai dengan hasil kerjanya tersebut. Menurut Wahyudi (2002:33), keterampilan adalah kecakapan atau keahlian untuk melakukan sesuatu pekerjaan hanya diperoleh dalam praktek. Menurut Peraturan Presiden No. 8 tahun 2012 pengertian keterampilan adalah kemampuan psikomotorik dan kemampuan menggunakan metode, bahan dan instrumen, yang diperoleh melalui pendidikan, pelatihan dan pengalaman kerja.

\section{Faktor-faktor yang mempengaruhi keterampi-} lan

Keterampilan kerja individu dapat ditentukan oleh dua faktor yaitu:

1. Kemampuan (ability), adalah pengetahuan dan keterampilan yang dimiliki oleh individu untuk menjalankan pekerjaanya agar menghasilkan pekerjaan yang terbaik.

2. Pengalaman (experience), merupakan kecakapan atau kemahiran yang dimiliki oleh individu untuk melakukan suatu pekerjaan dan hanya dapat diperoleh melalui praktek, baik latihan maupun melalui pengalaman.

Kedua faktor diatas dapat dikatakan sebagai tolak ukur dalam menentukan tingkat keterampilan kerja yang dimiliki oleh seseorang. Kecakapan dan pengalaman merupakan hal yang membentuk keterampilan seseorang.

\section{METODE PENELITIAN}

\section{Ruang Lingkup Penelitian}

Penelitian ini mendeskripsikan pengaruh pengetahuan, dan keterampilan terhadap kompetensi perajin sulaman minang di kelurahan koto panjang ikur koto kota Padang. Penelitian ini lebih diarahkan kepada perajin sulaman minang yang berada dibawah kelompok perajin sulaman di kelurahan koto panjang ikur koto Kota Padang. 


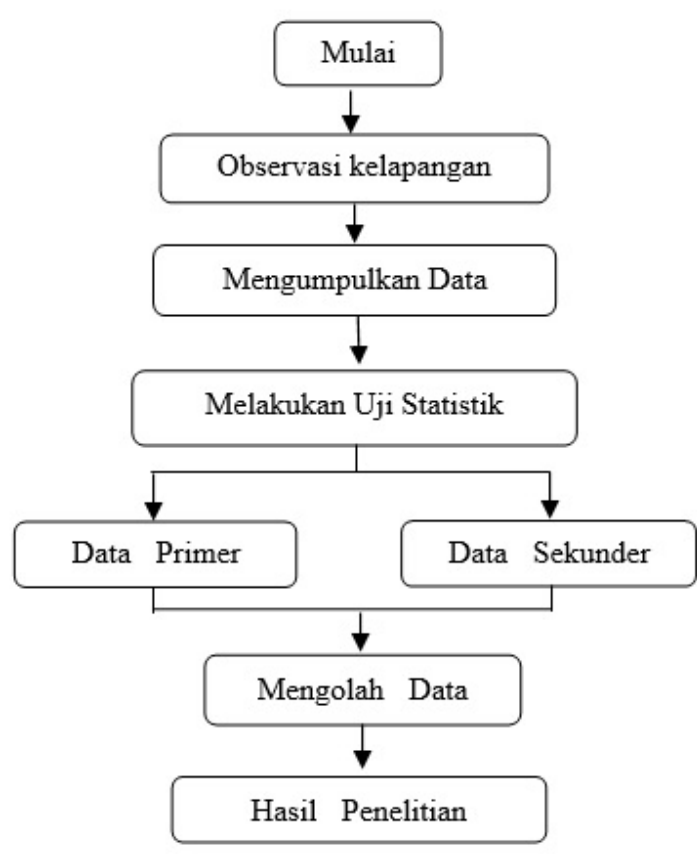

Gambar 2. Tahapan Penelitian

\section{Kerangka Konseptual}

Sebagai konsep untuk menjelaskan, mengungkapkan, dan menentukan persepsi keterkaitan antara variabel-variabel yang akan diteliti, berdasarkan permasalahan maupun antara variabel yang berpijak dari berbagai teori, maka secara konseptual dapat digambarkan sebagai berikut:

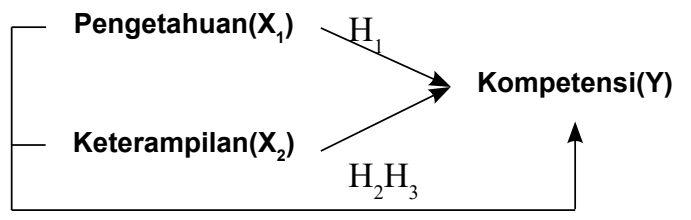

Gambar 3. Kerangka Konseptual

\section{Populasi dan Sampel}

Populasi dalam penelitian ini adalah perajin sulaman di kelurahan koto panjang ikur koto Kota Padang Tahun 2016.Pengambilan sampel menggunakan non probability sampling, Teknik pengambilan sampel dilakukan dengan purposive sampling, adalah teknik penentuan sampel dengan pertimbangan tertentu, misalnya penelitian sulaman maka yang dijadikan sampel perajin sulaman (Sugiyono, 2013:156).

\section{Jenis dan Sumber Data}

Jenis penelitian yang digunakan dalam pe- nelitian ini adalah penelitian kuantitatif deskriptif, dimana penelitian ini menjelaskan, menggambarkan, serta memperlihatkan hubungan sebab akibat antar variabelnya (Sugiyono, 2013:264).

\section{Sumber Data}

Data primer, yaitu data yang diperoleh langsung dari lapangan melalui penyebaran kuisioner kepada para responden. Jawaban responden dihimpun dan direkapitulasi untuk kemudian diolah.

Data sekunder, yaitu data yang diperoleh melalui studi kepustakaan yang relevan dengan bidang sumber daya manusia, seperti buku, jurnal, majalah, dari internetatau websiteyang menunjang penelitian ini.

\section{Teknik Pengumpulan Data}

Observasi, yaitu metode yang digunakan untuk melakukan pengamatan langsung terhadap kegiatan perajin sulaman di kelurahan ikur koto kota Padang.

Angket, yaitu metode yang digunakan untuk mendapatkan data primer, yaitu dengan cara membuat suatu daftar pernyataan yang secara sistematik dengan tujuan mendapatkan data yang diinginkan. Daftar pernyataan diedarkan kepada responden untuk dijawab.

Dokumentasi, yaitu metode yang digunakan untuk mendapatkan data yang bersumber kepada tulisan, seperti bukuyang relevan dengan bidang sumber daya manusia, jurnal, majalah, dari internetatau websiteserta data-data lain yang berhubungan dengan penelitian ini.

\section{Instrumen Penelitian}

Instrumen untuk mengumpulkan data dalam penelitian ini adalah dengan menggunakan beberapa pernyataan (kuisioner) yang disusun menggunakan skala Likert. Skala Likert adalah skala yang digunakan secara luas yang meminta responden menandai derajat persetujuan atau ketidaksetujuan terhadap masing-masing dari serangkaian pernyataan mengenai objek stimulus (Sugiyono, 2013:267). Setiap pernyataan mempunyai lima alternatif jawaban yang dapat dilihat pada tabel berikut ini: 
Tabel 2

Instrumen Penelitian (Skala Likert)

\begin{tabular}{clc}
\hline No. & \multicolumn{1}{c}{ Kategori } & Skor \\
\hline 1. & Sangat Tidak Setuju & 1 \\
\hline 2. & Tidak Setuju & 2 \\
\hline 3. & Cukup Setuju & 3 \\
\hline 4. & Setuju & 4 \\
\hline 5. & Sangat Setuju & 5 \\
\hline
\end{tabular}

Untuk memastikan bahwa instrumen yang digunakan dalam penelitian ini merupakan alat ukur yang akurat dan dapat dipercaya, maka digunakan dua macam pengujian, yaitu:

a. Uji Validitas

Menurut Sugiyono (2013:207), validitas adalah suatu ukuran yang menunjukkan tingkat kehandalan atau kesahihan suatu alat ukur. Untuk menghitung validitas alat ukur digunakan rumus pearson product moment.

$r_{\text {hitung }}=\frac{n\left(\Sigma X_{i} Y_{i}\right)-\left(\Sigma X_{i}\right) \cdot\left(\sum Y_{i}\right)}{\left.\sqrt{\left\{n \cdot \Sigma X_{i}^{2}\right.}-\left(\sum X_{i}\right)^{2}\right\} \cdot\left\{n \cdot \Sigma Y_{i}^{2}-\left(\sum Y_{i}\right)^{2}\right\}}$

Dimana:

$\mathrm{r}_{\text {hitung }}=$ Koefisien korelasi

$\Sigma \mathrm{X}_{\mathrm{i}} \quad=$ Jumlah skor item

$\Sigma \mathrm{Y}_{\mathrm{i}} \quad=$ Jumlah skor total (seluruh item)

$\mathrm{n}=$ Jumlah responden

\section{b. Uji Reliabilitas}

Uji reliabilitas menunjukkan sejauhmana suatu hasil pengukuran relatif konsisten apabila pengukuran terhadap aspek yang sama pada alat ukur yang sama. Menurut Sugiyono (2013) metode mencari reabilitas internal yaitu menggunakan reabilitias alat ukur satu kali pengukuran, rumus yang digunakan adalah alpha. Persamaannya adalah sebagai berikut:

$$
r_{1}=\left[\frac{k}{k-1}\right]\left[1-\frac{\sum S_{i}}{S_{t}}\right]
$$

Dimana:

$\mathrm{r}_{11}=$ Nilai reabilitas

$\Sigma \mathrm{S}_{\mathrm{i}}=$ Jumlah varians skor tiap-tiap item

$\mathrm{S}_{\mathrm{t}}=$ Varians total

$\mathrm{k}=$ Jumlah item
Alat ukur yang akan digunakan adalah dengan menggunakan cronbach alpha aplikasi SPSS (Statistic Product and Service Solution). Pengujian ini berguna untuk mengetahui apakah pengukuran yang dibuat reliabel. Untuk menentukan reliabel atau tidaknya butir-butir pernyataan, dilakukan dengan cara membandingkan koefisien alpha dengan nilai kritisnya pada $\alpha=0,05$ dengan kriteria pengujian sebagai berikut :

\section{Jika $\boldsymbol{r} x \boldsymbol{x} \geq \boldsymbol{r}_{\text {table, }}$ maka instrument reliabel. \\ Jika $r x x<r_{\text {table }}$, maka instrument tidak reliabel.}

\section{Teknik Analisis Data}

\section{Analisis Deskriptif}

Setelah data terkumpul kemudian disajikan ke dalam tabel distribusi frekuensi untuk dilakukan analisis deskriptif. Analisis ini digunakan untuk melihat gambaran secara umum tentang variabel yang diteliti dengan analisis persentase. Untuk mencari persentase jawaban angket dari responden digunakan rumus :

$$
P=\frac{f}{n} X 100 \%
$$

Dimana :

$\mathrm{P}=$ Persentase yang dicari

$\mathrm{F}=$ Frekuensi

$\mathrm{n}=$ Jumlah responden.

Untuk menghitung rata-rata skor masing-masing item digunakan rumus sebagai berikut :

$$
\mathrm{X}_{w}=\frac{\sum f_{i} w_{i}}{\sum f_{i}}
$$

Dimana:

STS $=$ Sangat Tidak Setuju

$\mathrm{S}=$ Setuju

TS $=$ Tidak Setuju

$\mathrm{SS}=$ Sangat Setuju

$\mathrm{CS}=$ Cukup Setuju

Menghitung nilai TCR masing-masing kategori jawaban dari deskriptif variabel, maka dapat dihitung dengan menggunakan rumus sebagai berikut:

$T C R=\underline{R s} x 100 \%$ 
Dimana :

TCR $=$ Tingkat capaian responden

Rs = Rata-rata skor jawaban responden

$\mathrm{N}$ = Jawaban responden

Pengkategorian nilai pencapaian responden digunakan klasifikasi:

$\begin{array}{ll}90 \%-100 \% & \text { Sangat baik } \\ 80 \%-89 \% & \text { Baik } \\ 65 \%-79 \% & \text { Sedang } \\ 55 \%-64 \% & \text { Buruk } \\ 0 \%-54 \% & \text { Sangat buruk. }\end{array}$

\section{Metode Analisis Data}

a. Uji Regresi Linear Berganda

Uji regresi linear berganda adalah sebuah pengujian statistik untuk mendapatkan gambaran pengaruh dari variabel independen terhadap variable dependen. Sugiyono (2013) secara umum merumuskan regresi linear berganda sebagai berikut:

$$
Y=a+b_{I} x_{1}+b_{2} x_{2}+e
$$

Dimana:

$\mathrm{Y}=$ Kompetensi

$b_{1,} b_{2}=$ Koefisien regresi

$\mathrm{x}_{1}=$ Pengetahuan

$\mathrm{x}_{2}=$ Keterampilan

e $=$ Disturbance error

b. Uji t

Menerapkan suatu uji statistik yang digunakan untuk melihat pengaruh variabel bebas terhadap variabel terikat secara parsial (sendiri), (Sugiyono, 2013). Pengujian hipotesis dilakukan dengan menggunakan t-test.

$$
T 0=\frac{b}{s b i}
$$

Dimana :

bi $=$ Koefisien regresi $\mathrm{X}_{\mathrm{i}}$

sbi $=$ Koefisien standar atas koefisien regresi $X_{i}$

to = Nilai yang dihitung / diobservasi

Kriteria pengujian:

Ho ditolak : Jika to $\geq \mathrm{t}$ Tabel atau - to $<-\mathrm{t}$ tabel

Ho diterima : Jika to $<\mathrm{t}$ Tabel atau - to $>-\mathrm{t}$ tabel. c. Uji F

Digunakan untuk melihat secara bersama-sama pengaruh variabel bebas berpengaruh terhadap variabel terikat, Sugiyono (2013) dengan rumus sebagai berikut:

$$
\boldsymbol{b}=\frac{R^{2} k-1}{\left(1-R^{2}\right)(n-1)}
$$

Dimana:

$\mathrm{R}^{2}=$ Koefisien (determinan) berganda

$\mathrm{n}$ = Besar sampel (banyak data)

$\mathrm{k}$ = Banyak variabel independen

Kriteria pengujian hipotesis:

Ho ditolak : Jika Fo $\geq$ F Tabel

Ho diterima $\quad$ : Jika Fo $<$ F Tabel

Dalam penelitian ini digunakan taraf signifikasi $5 \%$.

d. Uji determinasi $\left(\mathrm{R}^{2}\right)$

Dari hasil pengolahan data akan diperoleh koefisien determinasi yang telah disesuaikan $\mathrm{R}^{2}$ atau adjusted $\mathrm{R}$ Square sehingga akan diperoleh presentase dari Pengetahuan dan Keterampilan (X) terhadap Kompetensi (Y).

Dimana $\mathrm{R}^{2}=$ Koefisien determinasi,digunakan untuk mengidentifikasi kontribusi variabel bebas dalam mempengaruhi variabel terikat. Selanjutnya $\mathrm{R}=\sqrt{ } \mathrm{R}^{2}$ digunakan untuk melihat korelasi antara variabel bebas terhadap variabel terikat (Sugiyono, 2013)

$$
R^{2}=1-\frac{\sum \dot{\boldsymbol{e}}^{2}}{\sum \dot{\boldsymbol{y}}^{2}}
$$

Dimana :

$\mathrm{R}^{2}=$ Koefisien determinan

$\mathrm{ei}^{2}=$ Variabel penganggu

$e^{2}=$ Total jumlah kuadrat.

\section{HASIL PENELITIAN}

\section{Karakteristik Responden Berdasarkan Jenis Kelamin}

Berdasarkan Tabel 3, terlihat dari 60 responden 59 orang pesulam $(98,3 \%)$ berjenis kelamin pe rempuan. 
Tabel 3

Distribusi Frekuensi Responden Berdasarkan Jenis Kelamin Pengrajin Sulamandi Kelurahan Koto Panjang Ikur Koto Kota Padang

\begin{tabular}{llrrrr}
\hline & & & & & \multicolumn{2}{c}{ Cumulative } \\
& & Frequency & \multicolumn{1}{c}{ Percent } & Valid Percent & Percent \\
\hline Valid & LAKI-LAKI & 1 & 1.7 & 1.7 & 1.7 \\
& PEREMPUAN & 59 & 98.3 & 98.3 & 100.0 \\
& Total & 60 & 100.0 & 100.0 & \\
\hline
\end{tabular}

Sumber : Hasil Pengolahan data, 2017.

Tabel 4

Distribusi Frekuensi Responden Berdasarkan Usia

Pengrajin Sulamandi Kelurahan Koto Panjang Ikur Koto Kota Padang

\begin{tabular}{llrrrr}
\hline & & & & \multicolumn{2}{c}{ Cumulative } \\
& & Frequency & Percent & Valid Percent & Percent \\
\hline Valid & $>$ 18 Tahun & 4 & 6.7 & 6.7 & 6.7 \\
& 25 - 40 Tahun & 35 & 58.3 & 58.3 & 65.0 \\
& 41 - 60 Tahun & 21 & 35.0 & 35.0 & 100.0 \\
& Total & 60 & 100.0 & 100.0 & \\
\hline
\end{tabular}

Sumber: Hasil Pengolahan data, 2017.

Tabel 5

Distribusi Frekuensi Responden Berdasarkan Pendidikan Pengrajin Sulamandi Kelurahan Koto Panjang Ikur Koto Kota Padang

\begin{tabular}{llrrrr}
\hline & & & \multicolumn{2}{c}{ Cumulative } \\
& & Frequency & Percent & Valid Percent & Percent \\
\hline Valid & SD/SMP & 24 & 40.0 & 40.0 & 40.0 \\
& SMA & 34 & 56.7 & 56.7 & 96.7 \\
& Diploma/D3 & 1 & 1.7 & 1.7 & 98.3 \\
& S1 & 1 & 1.7 & 1.7 & 100.0 \\
& Total & 60 & 100.0 & 100.0 & \\
\hline
\end{tabular}

Sumber: Hasil Pengolahan data, 2017.

Tabel 6

Distribusi Frekuensi Responden Berdasarkan Pekerjaan Pengrajin Sulamandi Kelurahan Koto Panjang Ikur Koto Kota Padang

\begin{tabular}{llrrrr}
\hline & & & & \multicolumn{2}{c}{$\begin{array}{c}\text { Cumulative Per- } \\
\text { cent }\end{array}$} \\
\hline Valid & Frequency & Percent & Valid Percent & 6.7 & 6.7 \\
& PNS & 4 & 6.7 & 3.3 & 10.0 \\
& Wiiraswasta & 2 & 3.3 & 5.0 & 15.0 \\
& Ibu Rumah Tangga & 3 & 5.0 & 85.0 & 100.0 \\
& Total & 51 & 85.0 & 100.0 & \\
\hline
\end{tabular}

Sumber: Hasil Pengolahan data, 2017.

Tabel 7

Distribusi Frekuensi Responden Berdasarkan Pendapatan Pengrajin Sulamandi Kelurahan Koto Panjang Ikur Koto Kota Padang

\begin{tabular}{llrrrr}
\hline & & & & \multicolumn{2}{c}{ Cumulative } \\
Valid & Frequency & Percent & Valid Percent & Percent \\
\cline { 2 - 6 } & \multicolumn{1}{c}{ Rp. 1.500.000 } & 21 & 35.0 & 35.0 & 35.0 \\
& Rp 1.500.000 s/d 3.000.000 & 23 & 38.3 & 38.3 & 73.3 \\
Rp. 3.000.000 s/d 4.500.000 & 15 & 25.0 & 25.0 & 98.3 \\
& $>4.500 .000$ & 1 & 1.7 & 1.7 & 100.0 \\
Total & 60 & 100.0 & 100.0 & \\
\hline
\end{tabular}

Sumber : Lampiran hasil Pengolahan data, 2017. 
Karakteristik Responden Berdasarkan Usia

Berdasarkan Tabel 4 di atas, terlihat dari 60 responden, 35 orang pesulam $(58,3 \%)$ berusia 25 40 tahun dan responden yang berumur $>18$ tahun sebesar $6,7 \%$.

\section{Karakteristik Responden Berdasarkan Pen- didikan}

Berdasarkan Tabel 5 di atas, terlihat dari 60 responden 34 orang pengrajin sulaman $(56,7 \%)$ memiliki pendidikan SMA, kemudian SMP sebesar $40 \%$, seterusya tamatan D3 dan S1 masingmasing sebesar $1,7 \%$.

\section{Karakteristik Responden Berdasarkan Peker- jaan}

Berdasarkan Tabel 6 di atas, terlihat dari 60 responden 51 orang pengrajin sulaman $85,0 \%$ bekerja sebagai ibu rumah tangga (RT), 6,7\% pelajar/mahasiswa, 5,0\% wiraswasta dan PNS sebesar 3,3\%.

\section{Karakteristik Responden Berdasarkan Pendapatan}

Berdasarkan Tabel 7 di atas, terlihat dari 60 responden, yang pendapatannya terbanyak yaitu 23 orang pengrajin sulaman $(38,3 \%)$ memiliki penghasilan berkisar Rp 1.500.000 s/d 3.000.000, selebihnya35\% dibawah Rp 1.500 .000 dan 25\% pendapatan pengrajin diatas $\mathrm{Rp} 4.500 .000$.

\section{Karakteristik Responden Berdasarkan Lama Menjadi Pengrajin Sulaman}

Berdasarkan Tabel 8 di atas, terlihat dari 60 responden sebanyak24 orang pengrajin sulaman $(40,0 \%)$ lama bekerja sebagai pesulam $<2$ tahun kemudian 2-4 tahun sebesar 38.3\%, 4-6 tahun sebesar $18.3 \%$ menjadi pengrajin sulaman sampai lebih dari enam tahun menjadi pengrajin sulaman sebesar 3.3\% di Kelurahan Koto Panjang Ikur Koto Kota Padang.

\section{HASIL PENELITIAN}

Dari 60 angket yang diedarkan, maka semua angket dapat diolah dan ditabulasi untuk tujuan analisis data. Data yang ditabulasi adalah semua tanggapan atau jawaban dari responden atas setiap pernyataan yang ada dalam angket. Tabel berikut merupakan data hasil olahan angket yang merupakan deskripsi penelitian berdasarkan jawaban responden terhadap pernyataan variabel pengetahuan $\left(\mathrm{X}_{1}\right)$, keterampilan $\left(\mathrm{X}_{2}\right)$ terhadapkompetensi (Y).

\section{Pengetahuan $\left(\mathrm{X}_{1}\right)$}

Pada variabel pengetahuanindikator yang memiliki TCR tertinggiyaitu umur dengan item pertanyaan no 2 yaitu $84,33 \%$ adalah pengetahuan dalam menyulam semakin lama semakin baik, oleh sebab itu penyulam harus bisa mempertahankan pengetahuan mereka yang tinggi mengenai menyulam dengan menambah pengetahuan menyulam seperti mengikuti pelatihan-pelatihan, workshop dan lainnya. TCR terendah pada indikator lingkungan dengan item pertanyaan no 5 yaitu $68,00 \%$ yaitu lingkungan sekitar banyak yang menjadi pengrajin sulaman minang oleh sebab itu sebaiknya penyulam harus bisa meningkatkan kemampuan motivasi diri sendiri dalam menyulam meskipun di lingkungan tidak banyak yang memiliki pekerjaan sebagai penyulam.

\section{Keterampilan $\left(\mathbf{X}_{2}\right)$}

Pada variabel keterampilanindikator yang memiliki TCR tertinggi yaitu pengalaman dengan item pertanyaan no 4 yaitu $85,67 \%$ adalah keterampilan semakin bertambah dalam menyulam, karena pengalaman semakin meningkat dalam menyulam sulaman minang, oleh sebab itu pesulam harus bisa mempertahankan keterampilan mereka tentang menyulam mengenai menyulam. TCR terendah pada indikator kemampuan dengan item pertanyaan no 2 yaitu $74,67 \%$ adalah memiliki keterampilan yang bagus dalam menyulam sehingga mampu menyelesaikan sulaman dalam waktu singkat oleh sebab itu sebaiknya pesulam harus bisa meningkatkan kemampuan dalam me-nyulam.

\section{Kompetensi (Y)}

Pada variabel kompetensiindikator yang memiliki TCR tertinggiyaitu memilih desaign dan teknik sesuai teknik bordir dan sulaman dengan item pertanyaan no 2 yaitu 82,33\% mampu membedakan bermacam warna dan kombinasi warna, 
Tabel 8

Distribusi Frekuensi Responden Berdasarkan Lamanya Menjadi Penyulam di Kelurahan Koto Panjang Ikur Koto Kota Padang

\begin{tabular}{|c|c|c|c|c|c|}
\hline & & Frequency & Percent & Valid Percent & $\begin{array}{c}\text { Cumulative } \\
\text { Percent }\end{array}$ \\
\hline \multirow[t]{5}{*}{ Valid } & $<2$ Tahun & 24 & 40.0 & 40.0 & 40.0 \\
\hline & 2 - 4 Tahun & 23 & 38.3 & 38.3 & 78.3 \\
\hline & 4 - 6 Tahun & 11 & 18.3 & 18.3 & 96.7 \\
\hline & $>6$ Tahun & 2 & 3.3 & 3.3 & 100.0 \\
\hline & Total & 60 & 100.0 & 100.0 & \\
\hline
\end{tabular}

Sumber : Lampiran hasil Pengolahan data, 2017.

Tabel 9

Distribusi FrekuensiPengetahuan $\left(\mathrm{X}_{1}\right)$

\begin{tabular}{|c|c|c|c|c|c|c|c|c|c|c|c|c|c|c|c|}
\hline \multirow{3}{*}{ Indikator } & \multicolumn{11}{|c|}{ Pernyataan } & \multirow{3}{*}{$\mathbf{N}$} & \multirow{3}{*}{$\begin{array}{l}\text { Rata- } \\
\text { rata } \\
\text { skor }\end{array}$} & \multirow{3}{*}{ TCR } & \multirow{3}{*}{ Ket } \\
\hline & \multirow{2}{*}{$\begin{array}{l}\text { No. } \\
\text { Butir }\end{array}$} & \multicolumn{2}{|c|}{ STS } & \multicolumn{2}{|c|}{ TS } & \multicolumn{2}{|c|}{ BS } & \multicolumn{2}{|c|}{$\mathbf{s}$} & \multicolumn{2}{|c|}{ ss } & & & & \\
\hline & & $\mathbf{F}$ & $\%$ & $\mathbf{F}$ & $\%$ & $\mathbf{F}$ & $\%$ & $\mathbf{F}$ & $\%$ & $F$ & $\%$ & & & & \\
\hline \multirow{2}{*}{ Umur } & 1 & 2 & 3.3 & 2 & 3.3 & 8 & 13.3 & 30 & 50 & 18 & 30 & 60 & 48 & 80,00 & Baik \\
\hline & 2 & 1 & 1.7 & 1 & 1.7 & 6 & 8.3 & 33 & 55 & 20 & 33.3 & 60 & 50,6 & 84,33 & Baik \\
\hline \multirow{2}{*}{ Lingkungan } & 5 & 4 & 6.7 & 12 & 20 & 17 & 28.3 & 10 & 16.7 & 17 & 28.3 & 60 & 40,8 & 68,00 & Sedang \\
\hline & 6 & 3 & 5 & 0 & 0 & 20 & 33.3 & 24 & 40 & 13 & 21.7 & 60 & 44,8 & 74,67 & Sedang \\
\hline \multirow{2}{*}{ Pekerjaan } & 7 & 1 & 1.7 & 1 & 1.7 & 22 & 36.7 & 28 & 46.7 & 8 & 13.3 & 60 & 44,2 & 73,67 & Sedang \\
\hline & 8 & 1 & 1.7 & 4 & 6.7 & 18 & 30 & 27 & 45 & 10 & 16.7 & 60 & 44,2 & 73,67 & Sedang \\
\hline \multirow{2}{*}{ Informasi } & 9 & 0 & 0 & 0 & 0 & 18 & 30 & 38 & 633 & 4 & 16.7 & 60 & 45,2 & 75,33 & Sedang \\
\hline & 10 & 2 & 3.3 & 0 & 0 & 3 & 5 & 42 & 70 & 13 & 21.7 & 60 & 48,8 & 81,33 & Baik \\
\hline
\end{tabular}

Sumber : Olahan Data Sekunder, 2017.

Tabel 10

Distribusi Frekuensi Keterampilan $\left(\mathrm{X}_{2}\right)$

\begin{tabular}{|c|c|c|c|c|c|c|c|c|c|c|c|c|c|c|c|}
\hline \multirow{3}{*}{ Indikator } & \multirow{3}{*}{$\begin{array}{c}\text { No. } \\
\text { Butir }\end{array}$} & \multicolumn{10}{|c|}{ Pernyataan } & \multirow{3}{*}{$N$} & \multirow{3}{*}{$\begin{array}{l}\text { Rata- } \\
\text { rata } \\
\text { skor }\end{array}$} & \multirow{3}{*}{ TCR } & \multirow{3}{*}{ Ket } \\
\hline & & \multicolumn{2}{|c|}{ STS } & \multicolumn{2}{|c|}{ TS } & \multicolumn{2}{|c|}{ BS } & \multicolumn{2}{|c|}{$\mathbf{S}$} & \multicolumn{2}{|c|}{ SS } & & & & \\
\hline & & $\mathbf{F}$ & $\%$ & $F$ & $\%$ & $\mathbf{F}$ & $\%$ & $F$ & $\%$ & $F$ & $\%$ & & & & \\
\hline \multirow{2}{*}{ Kemampuan } & 1 & 0 & 0 & 2 & 3.3 & 3 & 5 & 42 & 70 & 13 & 21.7 & 60 & 49,2 & 82,00 & Baik \\
\hline & 2 & 0 & 0 & 3 & 5 & 20 & 33.3 & 27 & 45 & 10 & 16.7 & 60 & 44,8 & 74,67 & Sedang \\
\hline \multirow{2}{*}{ Pengalaman } & 3 & 0 & 0 & 1 & 1.7 & 3 & 5 & 42 & 70 & 14 & 16.7 & 60 & 49,8 & 83,00 & baik \\
\hline & 4 & 0 & 0 & 0 & 0 & 4 & 6.7 & 35 & 58.3 & 21 & 35 & 60 & 51,4 & 85,67 & Baik \\
\hline
\end{tabular}

Sumber : Olahan Data Sekunder, 2017.

oleh sebab itu penyulam harus bisa mempertahankan kemampuan mereka dalam membedakan warna dan mengkombinasikan warna sehingga konsumen tidak jenuh atau bosan dengan warna pada sulaman. TCR terendah pada indikator terampil mengerjakan berbagai teknik bordir sulaman dengan item pertanyaan no 3 yaitu 71,67\% yaitu mampu membuat produk sulaman dengan berbagai teknik sulam oleh sebab itu sebaiknya pesulam harus bisa meningkatkan kemampuan teknik menyulamnya dengan cara mengikuti pelatihan-pelatihan sulaman sehingga teknik menyulamnya semakin baik lagi.

\section{Uji Instrumen}

Pengujian Validitas Variabel Pengetahuan

Berikut ini ringkasan hasil pengujian validitas untuk item atau butir pertanyaan variabel pengetahuan dengan pendekatan koofisien korelasi untuk nilai $\mathrm{n}=30 \mathrm{r}_{\text {tabel }}=0,3640$ melalui Correlated Item Total Corelation yang disajikan pada Tabel 12.

Dari data Tabel 12, hasil pengujian validitas data pengetahuan yang dirancang dengan 10 item pertanyaan dari pengetahuan 1 sampai dengan pengetahuan 10, hasil analisis ditemukan 8 pertanyaan valid hal ini ditunjukan oleh nilai 
Tabel 11

Distribusi Frekuensi Kompetensi (Y)

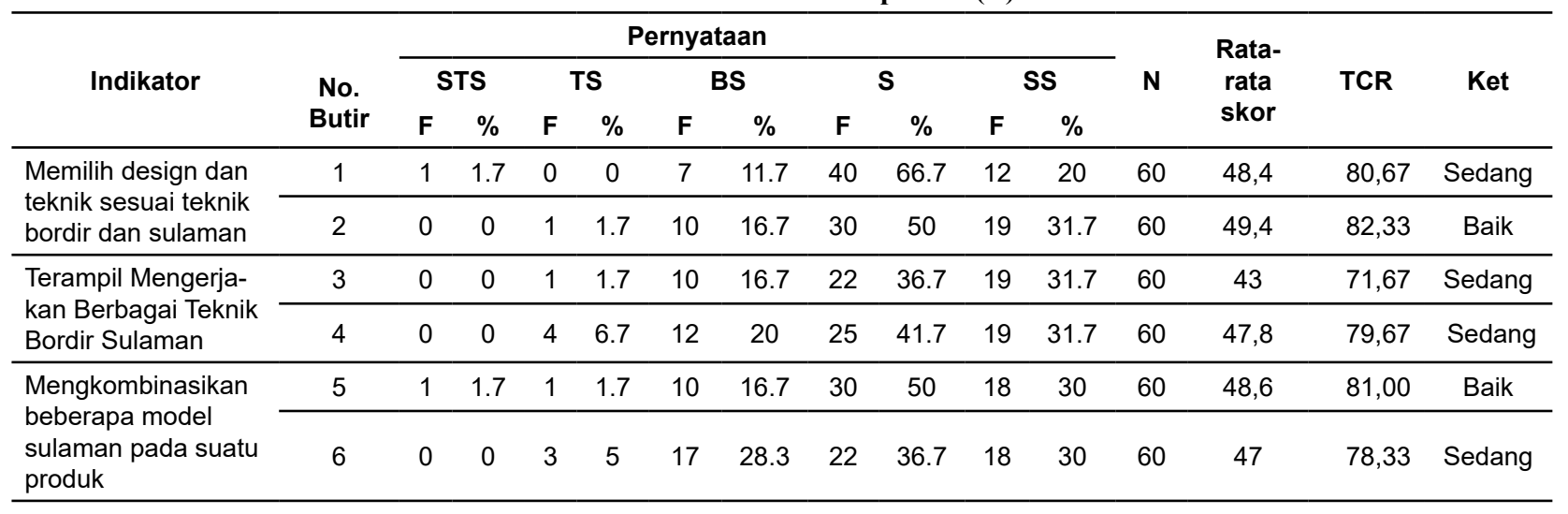

Sumber: Olahan Data Sekunder, 2017.

Tabel 12

Hasil Uji Validitas Pengetahuan

\begin{tabular}{ccccc}
\hline No & Pernyataan & $\begin{array}{c}\text { Corrected Item } \\
\text {-Total Correlation }\end{array}$ & $\mathbf{R}_{\text {tabel }}$ & Keterangan \\
\hline 1 & $\mathrm{X} 2.1$ & .582 & .254 & Valid \\
2 & $\mathrm{X} 2.2$ & .579 & .254 & Valid \\
3 & $\mathrm{X} 2.3$ & -.078 & .254 & Tidak Valid \\
4 & $\mathrm{X} 2.4$ & .207 & .254 & Tidak Valid \\
5 & $\mathrm{X} 2.5$ & .627 & .254 & Valid \\
6 & $\mathrm{X} 2.6$ & .557 & .254 & Valid \\
7 & $\mathrm{X} 2.7$ & .336 & .254 & Valid \\
8 & $\mathrm{X} 2.8$ & .547 & .254 & Valid \\
9 & $\mathrm{X} 2.9$ & .359 & .254 & Valid \\
10 & $\mathrm{X} 2.10$ & .524 & .254 & Valid \\
\hline
\end{tabular}

Sumber: Hasil pengolahan data, 2017

Tabel 13

Hasil Uji Validitas Keterampilan

\begin{tabular}{ccccc}
\hline No & Pernyataan & Corrected Item-Total Correlation & R $_{\text {tabel }}$ & Keterangan \\
\hline 1 & Y.1 & .513 & .254 & Valid \\
2 & Y.2 & .364 & .254 & Valid \\
3 & Y.3 & .501 & .254 & Valid \\
4 & Y.4 & .367 & .254 & Valid \\
\hline
\end{tabular}

Sumber: Hasil pengolahan data, 2017.

Tabel 14

Hasil Uji Validitas Kompetensi

\begin{tabular}{ccccc}
\hline No. & Pernyataan & Corrected Item-Total Correlation & $\mathbf{R}_{\text {tabel }}$ & Keterangan \\
1 & $\mathrm{X} 1.1$ & .595 & .254 & Valid \\
2 & $\mathrm{X} 1.2$ & .718 & .254 & Valid \\
3 & $\mathrm{X} 1.3$ & .833 & .254 & Valid \\
4 & $\mathrm{X} 1.4$ & .790 & .254 & Valid \\
5 & $\mathrm{X} 1.5$ & .661 & .254 & Valid \\
6 & $\mathrm{X} 1.6$ & .670 & .254 & Valid \\
\hline
\end{tabular}

Sumber: Hasil pengolahan data, 2017. 
koefisien yang $>0,3494$, dengan nilai koefisien korelasi seperti tabel diatas dan 2 pertanyaan tidak valid sehingga pernyataan tersebut tidak dilanjutkan dalam penelitian ini.

\section{Uji Validitas Variabel Keterampilan}

Berikut ini ringkasan hasil pengujian validitas untuk item atau butir pertanyaan variabel keterampilan dengan pendekatan koofisien korelasi untuk nilai $\mathrm{n}=30 \mathrm{r}_{\text {tabel }}=0,3640$ melalui Correlated Item Total Corelation yang disajikan pada Tabel 13.

Dari data Tabel 13 hasil pengujian validitas data keterampilan yang dirancang dengan 4 tem pertanyaan dari keterampilan1 sampai dengan keterampilan 4, secara keseluruhan semua item pertanyaan bernilai valid. Hal ini ditunjukan oleh nilai koefisien yang $>0,3494$, dengan nilai koefisien korelasi seperti tabel diatas.

\section{Pengujian Validitas Variabel Kompetensi}

Berikut ini ringkasan hasil pengujian validitas untuk item atau butir pertanyaan variabel kompetensi dengan pendekatan koofisien korelasi untuk nilai $\mathrm{n}=30 \mathrm{r}_{\text {tabel }}=0,3494$ melalui Correlated Item Total Corelation yang disajikan pada Tabel 14.

Dari data Tabel 14, hasil pengujian validitas data kompetensi yang dirancang dengan 6 item pertanyaan dari kompetensi 1 sampai dengan kompetensi 6, secara keseluruhan semua item pertanyaan sudah bernilai valid. Hal ini ditunjukan oleh nilai koefisien yang $>0,3494$ dengan nilai koefisien korelasi seperti tabel diatas.

\section{Uji Reabilitas}

Uji reabilitas bertujuan untuk menilai sejauh mana jawaban dari responden dapat memberikan hasil yang relatif berbeda (konsisten) bila dilakukan pengulangan pengukuran terhadap subjek yang sama. Instrumen reliabilitas (handal) berarti instrumen yang bila digunakan beberapa kali untuk mengukur objek yang sama, instrumen yang telah valid kemudian dilakukan uji realibilitas menggunakan rumus reliabilitas instrument ( $\mathrm{Al}$ pha Cronbachs) dengan bantuan SPSS versi I7. Jika $r$ alpha negatif dan lebih kecil dari $r$ tabel $(0,600)$ berarti keseluruhan butir instrumen tersebut reliable.

Berdasarkan Tabel 15 di atas terlihat nilai Apha Cronbachs menunjukkan hasil penilaian Uji Reliabilitas dari masing-masing variabel, dimana nilai Alpha Cronbachs secara keseluruhan variabel $>0,600$ oleh karena itu seluruh variabel penelitian dikatakan reliabel/handal.

\section{Analisis Regresi Linear Berganda}

Analisis statistik yang digunakan dalam penelitian ini yaitu regresi linear berganda. Analisis ini digunakan untuk mengetahui besarnya pengaruh variabel-variabel bebas (independen) yaitu pengetahuan dan keterampilan terhadap variabel terikat (dependen) yaitu kompetensi.

Hasil dari regresi linear berganda adalah sebagai berikut:

$$
Y=6.641+0.020 X_{1}+0.297 X_{2}+e
$$

a. Nilai constanta 6.641 artinya jika pengetahuan $\left(\mathrm{X}_{1}\right)$ dan keterampilan $\left(\mathrm{X}_{2}\right)$ tidak mengalami perubahan atau $\mathrm{X}_{1}=\mathrm{X}_{2}=0$, maka kompetensi penyulam sudah ada sebesar 6.641 satuan.

b. Nilai koefisien regresi pengetahuan $\left(\mathrm{X}_{1}\right)$ adalah 0.020 artinya jika variabel pengetahuan $\left(\mathrm{X}_{1}\right)$ meningkat sebesar 1 (satuan) dengan asumsi variabel keterampilan $\left(\mathrm{X}_{2}\right)$ tetap (constan) atau 0 (nol,) maka kompetensi penyulam meningkat sebesar 0.020 satuan.

c. Nilai koefisien regresi keterampilan $\left(\mathrm{X}_{2}\right)$ ada-

Tabel 15

Uji Reabilitas

\begin{tabular}{|c|c|c|c|}
\hline No & Variabel & Crombach Alpha & Keterangan \\
\hline 1 & Pengetahuan & 0.811 & Realibel \\
\hline 2 & Kompetensi & 0.891 & Realibel \\
\hline 3 & Keterampilan & 0.661 & Realibel \\
\hline
\end{tabular}

Sumber : Olahan Data Sekunder, 2017. 
lah 0.297 artinya jika variabel keterampilan $\left(\mathrm{X}_{2}\right)$ meningkat sebesar 1 (satuan) dengan asumsi variabel pengetahuan $\left(\mathrm{X}_{1}\right)$ tetap (constan) atau 0 (nol,) maka kompetensi penyulam meningkat sebesar 0.0297 satuan.

\section{Uji t}

Uji $\mathrm{t}$ dimaksudkan untuk mengetahui pengaruh secara parsial (individu) variabel-variabel bebas (Pengetahuan dan Keterampilan) terhadap variabel terikat (Kompetensi) atau menguji signifikansi konstanta dan variabel terikat.

\section{Pengujian Hipotesis Pertama $\left(\mathrm{H}_{1}\right)$}

Dari Tabel 16 nilai $t_{\text {hitung }}$ variabel pengetahuan adalah 0.289 dengan probabilitas signifikan sebesar 0.774. Probabilitas signifikansi tersebut lebih kecil dari 0,05. Dengan $\mathrm{df}=\mathrm{n}-\mathrm{k}=60-2=58$ diperoleh $\mathrm{t}_{\text {tabel }}$ sebesar 1.672 , dari hasil di atas dapat dilihat bahwa $t_{\text {hitung }}>t_{\text {tabel }}$ atau $0.289>1.672$, maka variabel pengetahuan berpengaruh signifikan terhadap kompetensi, maka dapat disimpulkan bahwa hipotesis $(\mathrm{Ha})$ yang berbunyi pengetahuan $\left(\mathrm{X}_{1}\right)$ berpengaruh signifikan terhadap kompetensi (Y), maka dengan demikian hipotesis pertama $\left(\mathrm{H}_{1}\right)$ diterima.

\section{Pengujian Hipotesis Kedua $\left(\mathbf{H}_{2}\right)$}

Dari tabel 4.11 nilai $_{\text {hitung }}$ variabel keterampilan adalah 5.048 dengan probabilitas signifikan sebesar 0,000. Probabilitas signifikansi tersebut lebih kecil dari 0,05. Dengan df $=\mathrm{n}-\mathrm{k}=60-2=$ 58 diperoleh $t_{\text {tabel }}$ sebesar 1.672 , dari hasil di atas dapat dilihat bahwa $t_{\text {hitung }}>\mathrm{t}_{\text {tabel }}$ atau $0.000<1.672$, maka variabel keterampilan berpengaruh signifikan terhadap kompetensi, maka dapat disimpulkan bahwa hipotesis (Ha) yang berbunyi keterampilan $\left(\mathrm{X}_{2}\right)$ berpengaruh signifikan terhadap kompetensi

Tabel 16

Hasil Perhitungan Uji t

Coefficients $^{\mathrm{a}}$

\begin{tabular}{|c|c|c|c|c|c|c|}
\hline \multirow{2}{*}{ Model } & \multirow[b]{2}{*}{ B } & \multicolumn{2}{|c|}{ Unstandardized Coefficients } & \multirow{2}{*}{$\begin{array}{l}\text { Standardized } \\
\text { Coefficients }\end{array}$} & \multirow[b]{2}{*}{$\mathbf{t}$} & \multirow[b]{2}{*}{ Sig. } \\
\hline & & Std. Error & Beta & & & \\
\hline \multirow[t]{3}{*}{1} & (Constant) & 6.641 & 1.728 & & 3.843 & .000 \\
\hline & Pengetahuan & .020 & .070 & .035 & .289 & .774 \\
\hline & Keterampilan & .297 & .059 & .609 & 5.048 & .000 \\
\hline
\end{tabular}

a. Dependent Variable: KOMPETENSI

Sumber : Pengolahan data primer, 2017

Tabel 17

Uji F

ANOVA $^{b}$

\begin{tabular}{llrrrrr}
\hline Model & & Sum of Squares & df & Mean Square & F & Sig. \\
\hline 1 & Regression & 119.835 & 2 & 59.917 & 18.580 & $.000^{a}$ \\
& Residual & 183.815 & 57 & 3.225 & & \\
& Total & 303.650 & 59 & & & \\
\hline
\end{tabular}

a. Predictors: (Constant), PENGETAHUAN, KOMPETENSI

b. Dependent Variable: KETERAMPILAN

Sumber : Pengolahan data primer, 2017

Table 18

Uji R Square

Model Summary ${ }^{\mathrm{b}}$

\begin{tabular}{|c|c|c|c|c|c|c|c|c|c|c|}
\hline \multirow[b]{2}{*}{ Model } & \multirow[b]{2}{*}{$\mathbf{R}$} & \multirow[b]{2}{*}{$\begin{array}{c}\mathbf{R} \\
\text { Square }\end{array}$} & \multirow[b]{2}{*}{$\begin{array}{l}\text { Adjusted } \\
\text { R Square }\end{array}$} & \multirow{2}{*}{$\begin{array}{l}\text { Std. Error } \\
\text { of the } \\
\text { Estimate }\end{array}$} & \multicolumn{5}{|c|}{ Change Statistics } & \multirow[b]{2}{*}{$\begin{array}{l}\text { Durbin- } \\
\text { Watson }\end{array}$} \\
\hline & & & & & $\begin{array}{c}\text { R Square } \\
\text { Change }\end{array}$ & $\begin{array}{c}F \\
\text { Change }\end{array}$ & df1 & df2 & $\begin{array}{c}\text { Sig. F } \\
\text { Change }\end{array}$ & \\
\hline 1 & $.628^{\mathrm{a}}$ & .395 & .373 & 1.79578 & .395 & 18.580 & 2 & 57 & .000 & 1.662 \\
\hline
\end{tabular}

a. Predictors: (Constant), PENGETAHUAN, KOMPETENSI

b. Dependent Variable: KETERAMPILAN

Sumber : Pengolahan data primer, 2017 
$(\mathrm{Y})$, maka dengan demikian hipotesis kedua $\left(\mathrm{H}_{2}\right)$ diterima.

\section{Uji F}

Uji F digunakan untuk melihat pengaruh secara keseluruhan dari variabel independen dengan variabel dependent, dengan bantuan program SPSS diketahui nilai $\mathrm{F}_{\text {hitung }}$ pada Tabel Anova.

Dari uji Anova dapat dinilai $\mathrm{F}_{\text {hitung }}$ sebesar 18.580 dengan probabilitas signifikansi 0.000 . Probabilitas signifikansi tersebut lebih kecil dari 0,05 maka dapat disimpulkan terdapat pengaruh pengetahuan dan keterampilan dengan kompetensi pengrajin sulamandi Kelurahan Koto Panjang Ikur Koto Kota Padang.

\section{Koefisien Determinan $\left(\mathbf{R}^{2}\right)$}

Nilai $\mathrm{R}^{2}(R$-Square) digunakan untuk mengukur seberapa besar proporsi variasi dari variabel independen secara bersama-sama dalam mempengaruhi variabel dependent. Berdasarkan hasil pengolahan data diketahui bahwa nilai Uji $\mathrm{R}^{2}$ (Adjusted R-Square) adalah sebesar 0,373 hal ini berarti besarnya pengaruh pengetahuan dan keterampilan secara bersama-sama berpengaruh terhadap kompetensi penyulam di Kelurahan Koto Panjang Ikur Koto Kota Padang adalah sebesar $37,3 \%$ sisanya sebesar $62.7 \%$ dijelaskan oleh variabel lain yaitu yang tidak masuk ke dalam penelitian ini.

\section{PEMBAHASAN}

\section{Pengaruh Pengetahuan terhadap Kompetensi}

Berdasarkan hasil penelitian ditemukan nilai $t_{\text {hitung }}$ variabel pengetahuan adalah 0.289 dengan probabilitas signifikan sebesar 0,774 . Probabilitas signifikansi tersebut lebih kecil dari 0,05. Dengan $\mathrm{df}=\mathrm{n}-\mathrm{k}=60-2=58$ diperoleh $\mathrm{t}_{\text {tabel }}$ sebesar 1.672, dari hasil di atas dapat dilihat bahwa $t_{\text {hitung }}>t_{\text {tabel }}$ atau 5.048> 1.672, maka variabel pengetahuan berpengaruh signifikan terhadap kompetensi.

Mempunyai kompetensi yang baik maka seorang individu harus memiliki pengetahuan yang luas dan terkini agar dapat menyesuaikan dengan perubahan yang terjadi. Sebagian besar pengetahuan manusia di peroleh melalui mata dan telinga, untuk itu sebagai pengrajin sulaman harus memi- liki ketajaman penglihatan (mata) agar mampu menyulam lebih teliti dan mampu membedakan warna sehingga sulaman yang dihasilkan bagus, kuat dan memiliki warna yang disukai konsumen. Pengetahuan adalah merupakan hasil mengingat suatu hal, termasuk mengingat kembali kejadian yang pernah dialami baik secara sengaja maupun tidak sengaja dan ini terjadi setelah orang melakukan kontak atau pengamatan terhadap suatu obyek tertentu (Mubarak, 2007). Menurut Peraturan Presiden No. 8 tahun 2012 pengertian pengetahuan adalah penguasaan dan pemahaman tentang konsep, fakta, informasi, teori dan metodologi pada bidang keilmuan, keahlian dan pekerjaan tertentu oleh seseorang.

\section{Pengaruh Keterampilan terhadap Kompetensi}

Berdasarkan hasil penelitian ditemukan nilai $t_{\text {hitung }}$ variabel keterampilan adalah 5.048 dengan probabilitas signifikan sebesar 0,000 . Probabilitas signifikansi tersebut lebih kecil dari 0,05. Dengan $\mathrm{df}=\mathrm{n}-\mathrm{k}=60-2=58$ diperoleh $\mathrm{t}_{\text {tabel }}$ sebesar 1.672, dari hasil di atas dapat dilihat bahwa $t_{\text {hitung }}>t_{\text {tabel }}$ atau $0.774<1.672$, maka variabel keterampilan berpengaruh signifikan terhadap kompetensi.

Keterampilan kerja memiliki manfaat yang besar bagi individu, untuk dapat meningkatkan hasil kerjanya sehingga memperoleh balas jasa yang sesuai dengan hasil kerjanya tersebut. Pengrajin sulaman wajib memiliki keterampilan dan menyulam. Tampa terampil dalam menyulam maka pengrajin sulaman tidak akan mampu membuat dan menghasilkan sulaman yang berkualitas bagus dan memiliki nilai jual dipasar. Menurut Wahyudi (2002:33) yaitu keterampilan adalah kecakapan atau keahlian untuk melakukansesuatu pekerjaan hanya di peroleh dalam praktek. Menurut Peraturan Presiden No. 8 tahun 2012 pengertian keterampilan adalah kemampuan psikomotorik dan kemampuan menggunakan metode, bahan dan instrumen, yang diperoleh melalui pendidikan, pelatihan dan pengalaman kerja.

\section{Pengaruh Pengetahuan dan Keterampilan terhadap Kompetensi}

Dari uji Anova dapat dinilai $\mathrm{F}_{\text {hitung }}$ sebesar 15.580 dengan probabilitas signifikansi 0.000 . Probabilitas signifikansi tersebut lebih kecil dari 
0,05 maka dapat disimpulkan terdapat pengaruh pengetahuan dan keterampilan dengan kompetensi pengrajin sulamandi Kelurahan Koto Panjang Ikur Koto Kota Padang.

Nilai $\mathrm{R}^{2}$ (R-Square) digunakan untuk mengukur seberapa besar proporsi variasi dari variabel independen secara bersama-sama dalam mempengaruhi variabel dependent. Berdasarkan hasil pengolahan data diketahui bahwa nilai $\mathrm{Uji}$ $\mathrm{R}^{2}$ (Adjusted R-Square) adalah sebesar 0,373 hal ini berarti besarnya pengaruh pengetahuan dan keterampilan secara bersama-sama berpengaruh terhadap kompetensi pengrajin sulamandi Kelurahan Koto Panjang Ikur Koto Kota Padang adalah sebesar 37,3\% sisanya dijelaskan oleh variabel lain yaitu yang tidak masuk dalam penelitian ini.

Spencer dan Spencer dalamUno(2007:63), kompetensi merupakankarakteristikyang menonjolbagiseseorang danmenjadicara-cara berperilakudanberfikirdalamsegala situasi,danberlangs ungdalamperiode waktuyanglama.Daripendapattersebutdapatdipahamibahwa kompetensi menunjukpada pengetahuan dan keterampilan yang dimiliki seseorang dalamsuatupekerjaanyang bisadilihatdari pikiran,sikap,danperilaku kerja. Dessler (2004: 713) menyatakan bahwa kompetensi adalah mengacu pada pengetahuan (knowledge), keterampilan (skill), individu yang secara langsung mempengaruhi kinerja, sehingga untuk bekerja dan menghasilkan hasil terbaik maka dalam penelitian ini pengrajin sulaman minang harus mampu mengkombinasikan pengetahuan dan keterampilan yang mereka miliki agar menjadi kompetensi bagi pengrajin sulaman yang sangat bermanfaat dalam menjalankan kegiatan mereka sebagai pengrajin sulaman. Memiliki kompetensi bagus maka hasil yang dihasilkan dari kegiatan atau pekerjaan pengrajin pun bagus dengan kata lain mampu membuat dan menghasilkan sulamansulaman yang bermutu dan berkualitas bagus dan memiliki daya jual tinggi.

\section{KESIMPULAN}

1. Hasil uji t, diketahui pengetahuan berpengaruh signifikant terhadap variabel kompetensi secara parsial dimana nilai $t_{\text {hitung }}$ variabel pengetahuan adalah 0.289 dengan probabilitas sig- nifikan sebesar 0.774. Probabilitas signifikansi tersebut lebih kecil dari 0,05. Dengan $\mathrm{df}=\mathrm{n}-\mathrm{k}$ $=60-2=58$ diperoleh $\mathrm{t}_{\text {tabel }}$ sebesar 1.672, dari hasil di atas dapat dilihat bahwa $\mathrm{t}_{\text {hitung }}>\mathrm{t}_{\text {tabel }}$ atau $0.289>1.672$, maka variabel pengetahuan berpengaruh signifikan terhadap kompetensi.

2. Hasil uji t, diketahui keterampilan berpengaruh signifikant terhadap variabel kompetensi secara parsial dimana nilai $t_{\text {hitung }}$ variabel keterampilan adalah 5.048 dengan probabilitas signifikan sebesar 0,000. Probabilitas signifikansi tersebut lebih kecil dari 0,05. Dengan df $=\mathrm{n}-\mathrm{k}=60-2=58$ diperoleh $\mathrm{t}_{\text {tabel }}$ sebesar 1.672, dari hasil di atas dapat dilihat bahwa $t_{\text {hitung }}>\mathrm{t}_{\text {tabel }}$ atau $0.000<1.672$, maka variabel keterampilan berpengaruh signifikan terhadap kompetensi.

3. Hasil uji $\mathrm{R}^{2}$ diperoleh 0,373 hal ini berarti besarnya pengaruh pengetahuan dan keterampilan secara bersama-sama perpengaruh terhadap kompetensi penyulam di Kelurahan Koto Panjang Ikur Koto Kota Padang adalah sebesar $7,3 \%$ sisanya sebesar $62.7 \%$ dijelaskan oleh variabel lain yaitu yang tidak masuk ke dalam penelitian ini.

\section{SARAN}

1. Sebaiknya untuk meningkatkan pengetahuan penyulam diberikan pelatihan-pelatihan mengenai teknik menyulam yang baik agar mereka lebih memiliki pengetahuan mengenai penyulaman seperti teknik menyulam dan cara membuat motif sulaman. Jadi pengrajin sulaman minang akan mampu membuat dan menghasilkan motif sulaman yang sesuai dengan keinginan konsumen dan keinginan pasar.

2. Sebaiknya keterampilan penyulam juga lebih ditingkatkan dengan cara memberikan motivasi kepada penyulam agar lebih memiliki semangat dalam menyulam serta kreatif dalam membuat sulaman sehingga sesuai dengan keinginan konsumen dan pasar.

3. Agar kompetensi penyulam semakin bagus maka diharapkan kepada pemerintah daerah kota Padang untuk lebih sering atau terjadwa setiap tahunnya untuk memberikan pelatihan, workshop dan kegiatan lainnya dalam meningkatkan kompetensi pengrajin sulaman minang. 


\section{REFERENSI}

Dessler, Gary. 2004. Manajemen Sumber Daya Manusia. Gramedia. Jakarta.

Krafsulam.blogspot.com

Mubarak, Wahit Iqbal.2007.Ilmu Keperawatan Komunitas Konsep dan aplikasi.Salemba Medika. Jakarta.

Notoatmodjo, S. 2007.Pendidikan dan Perilaku Kesehatan. Rineka Cipta. Jakarta.

Palan, R. 2007. Competency Management. Teknik mengimplementasikan Manajemen SDM berbasis kompetensi untuk meningkatkan daya saing Organisasi. Penerjemah Octa Melia Jalal. PPM. Jakarta.

Peraturan Presiden No. 8 tahun 2012 tentang standar kompetensi lulusan (SKL) kursus dan pelatihan sulam.

Sugiyono. 2013. Metode Penelitian Manajemen. Alfabeta. Bandung.

Sutrisno, Edi. 2012. Manajemen Sumber Daya Manusia. Kencana Prenada Media Group. Jakarta.

Uno B. Hamzah. 2007. Teori Motivasi dan Pengukurannya analisis di Bidang Pendidikan. Bumi Aksara. Jakarta.

Wahyudi, Bambang. 2002. Manajemen Sumber Daya Manusia. Sulita. Bandung.

Wibowo. 2007. Manajemen Kinerja. PT. Raja Grafindo Persada. Jakarta.

Yuniarsih, Tjutju. Suwatno. 2011. Manajemen Sumber Daya Manusia. CV. Alfabeta. Jakarta. 
